九州大学学術情報リポジトリ

Kyushu University Institutional Repository

The Nitrogen Supplying Capacities,

Transformation of Fixed Ammonium and Chemical

Nature of Decomposable Organic Nitrogen through

the Successively Air-drying or Oven-drying,

Rewetting and Incubation of Residual Soils Amended with $15^{\wedge} \mathrm{N}-$ Labelled Rice Straw

Kawaguchi, Sadao

Laboratory of Soil Microbiology and Biochemistry, Faculty of Agriculture, Kyushu University

Kai, Hideaki

Laboratory of Soil Microbiology and Biochemistry, Faculty of Agriculture, Kyushu University

Aibe, Toshiharu

Laboratory of Soil Microbiology and Biochemistry, Faculty of Agriculture, Kyushu University

https://doi.org/10.5109/23828

出版情報: 九州大学大学院農学研究院紀要. 30 (4)，pp.253-265，1986-09. Kyushu University バージョン：

権利関係: 


\title{
The Nitrogen Supplying Capacities, Transformation of Fixed Ammonium and Chemical Nature of Decomposable Organic Nitrogen through the Successively Air-drying or Oven-drying, Rewetting and Incubation of Residual Soils Amended with ${ }^{15} \mathbf{N}$-Labelled Rice Straw
}

\author{
Sadao Kawaguchi, Hideaki Kai and Toshiharu Aibe \\ Laboratory of Soil Microbiology and Biochemistry, Faculty of Agriculture, \\ Kyushu University 46-02, Fukuoka 812
}

(Received March 12, 1986)

\begin{abstract}
On the repeated either air-drying or oven-drying, rewetting and incubation of residual soils amended with ${ }^{15} \mathrm{~N}$-labelled rice straw, the nitrogen supplying capacities of soils, transformation of fixed ammonium and chemical nature of decomposable organic nitrogen were investigated. The results were summarized as follows :

1). The mineralization of nitrogen derived from rice straw of residual soils was remarkably accelerated at the early stage of incubation due to both air-drying and oven-drying effects. The magnitude of a flush of mineral nitrogen was much greater in the latter than in the former. On the contrary, the mineralization of the native soil-N was continued at a fairly steady rate by the later stage of incubation. These results would account for the necessity of successively long-term application of rice straw to increase the nitrogen supplying capacities of soil.

2). A small portion of rice straw-N was fixed by soils during the mineralization process of rice straw. The application of rice straw to soils resulted in the promotion of the release of the native soil fixed ammonium, and the magnitudes of the priming effect were approximately in inverse proportion to the amounts of native fixed ammonium of soils. Ammonium mineralized due to the air-drying of residual soils was slightly fixed, while the repeated oven-drying, rewetting and incubation led to a marked increase of fixed ammonium derived from both rice straw-N and soil-N. The percentages of newly fixed ammonium of mineralized nitrogen of rice straw-N and soil-N due to the oven-drying effect ranged from 2.3 to $9.1 \%$ and from 1.6 to $9.7 \%$, respectively.

3). As compared with the native soil-N, rice straw-N of the residual soils was found more in amino acid-N and unidentified-N, and comparable percentages were present in hexosamine-N and ammonium-N of the acid hydrolyzable-N. The principal fractions of organic nitrogen becoming decomposable through either air-drying or oven-drying of soils existed in unidentified-N and amino acid-N. Their susceptibilities to mineralization were much greater in the nitrogen fractions derived from rice straw-N than those from the soil-N. The susceptibility of hexosamine-N to the mineralization due to the air-drying effect was considerably lower than those of unidentified-N and amino acid-N, but enhanced significantly through the oven-drying of soils followed by rewetting and incubation.
\end{abstract}




\section{INTRODUCTION}

The return of rice straw to the field is a very useful and practical met hod which enables not only to supplement the nutrition for rice production but also to maintain soil fertility (Broadbent, et al., 1979). In the previous paper (Masayna et al., 1984; Kawaguchi et al., 1986), the application of rice straw was effective to accumulate a decomposable organic nitrogen in soil and increase the nitrogen supplying capacities of soils. So far, many experiments (Birch 1958 ; Hayashi and Harada, 1969; Kai et al., 1973 ; Ahmad et al., 1973) have been reported that the drying of soils causes a flush decomposition of soil organic nitrogen. The rates of decomposition depend on the degree of desiccation at which the soil was dried. In the previous study (Kai et al., 1973 ; Ahmad et al., 1973), it was assumed that a large portion of the nitrogen compounds becoming decomposable through the effect of drying of a soil is originated from peptide complex materials of microbial cell walls in the soil receiving glucose and potassium nitrate labelled with ${ }^{15} \mathrm{~N}$.

The soils containing 2 : 1 clay minerals such as vermiculite, illite and montmorillonite have been shown to entrap ammonium ions between the silicate sheets (Broadbent, 1979). The lower the soil moisture becomes, the greater the fixation of ammonium progresses. The fixation of ammonium applied as fertilizer is generally considered to lessen its availability to plants (Black and Waring, 1972 ; Kai and Wada, 1979). A similar data for the transformation of fixed ammonium derived from mineralization of the added organic matter labelled with ${ }^{15} \mathrm{~N}$ has been very little.

The present study was carried out to obtain the information about 1) residual effect of rice straw application on nitrogen supplying capacities of soils, 2) transformation of fixed ammonium in soils during the decomposition of added rice straw and following the successively repeated either air-drying or ovendrying, rewetting and incubation of soils, and 3) the chemical nature of organic nitrogen becoming decomposable through the drying of residual soils amended with ${ }^{15} \mathrm{~N}$-labelled rice straw.

\section{MATERIALS AND METHODS}

\section{Soil samples}

Three soils used in this experiment were the amended soils with ${ }^{15} \mathrm{~N}$-labelled rice straw following 28 weeks' incubation under upland condition conducted in the previous study (Kawaguchi et al., 1986). The soils were leached with deionized water to obtain soil free from mineral nitrogen. They contained the organic nitrogen derived from rice straw-N and native soil-N, respectively on $100 \mathrm{~g}$ dry weight basis as follows : 56.2 and $1,087 \mathrm{mg} \mathrm{N}$ in Nagano soil, 53.0 and $1,984 \mathrm{mg} \mathrm{N}$ in Kasuya soil, and 55.7 and 3,528 $\mathrm{mg} \mathrm{N}$ in Miyakonojo soil.

\section{Drying, rewetting and incubation of soils}

The moist residual soils prepared as above, corresponding to $200 \mathrm{~g}$ dry soil were air-dried for 3 days at room temperature and oven-dried for 3 hours at 
$80^{\circ} \mathrm{C}$, respectively. The soil of each treatment was put into a cylindrical flask $(15 \mathrm{~cm}$ in diameter and $12 \mathrm{~cm}$ high) attached with a sintered glass. After the inoculation of each moist soil, the soil moisture was brought to $60 \%$ of maximum water holding capacity by adding of deionized water. The flasks were covered with polyethylene film and incubated at $30^{\circ} \mathrm{C}$ for 3 weeks. Thereafter the soils in the flasks were washed with deionized water and filtered using suction to remove all nitrates. The treatments of drying, rewetting, incubation and washing were repeated 6 times to make the flush decomposition of the soil organic matter derived from rice straw-N and soil-N.

\section{Determination of mineral nitrogen and different forms of organic nitrogen}

After a certain incubation intervals, a part of soil samples was taken out from the incubation flasks for the determination of mineral nitrogen (Kai and Harada, 1972), fixed ammonium nitrogen (Silva and Bremner, 1966), and organic forms in the acid hydrolysate (Bremner, 1975). The isotopic ratio of each fraction of nitrogen was determined by the same method described in the previous paper (Kawaguchi et al., 1986).

\section{RESULTS AND DISCUSSION}

\section{Nitrogen supplying capacities of residual soils through either the air-drying or oven-drying effect}

To assess the nitrogen supplying capacities of the residual soils after 28 weeks' incubation, the soils were given 6 times treatments of drying, rewetting and incubation for 3 weeks. The cumulative nitrogen mineralized during a total of 18 weeks' incubation of residual soils was shown in Fig. 1.

On the repeated air-drying, rewetting and incubation of residual soils, the mineralization of nitrogen derived from rice straw- $\mathrm{N}$ was greatest in the first

Table 1. Mineralization of rice straw-N and soil-N of residual soils which were successively treated 6 times with drying, rewetting and incubation, expressed as mg $\mathrm{N}$ per $100 \mathrm{~g}$ dry soil.

\begin{tabular}{|c|c|c|c|c|c|}
\hline \multirow{2}{*}{ Treatment } & \multirow{2}{*}{\multicolumn{3}{|c|}{ Nagano }} & \\
\hline & & & & Kasuya & Miyakonojo \\
\hline \multirow{3}{*}{$\begin{array}{l}\text { Air-drying } \\
\text { and } \\
\text { rewetting }\end{array}$} & Rice & straw-N & $\begin{array}{l}10.7 \\
(19.0)\end{array}$ & $\begin{array}{c}10.4 \\
(19.6)\end{array}$ & $\begin{array}{c}6.2 \\
(11.1)\end{array}$ \\
\hline & Soil & $-\mathrm{N}$ & $(8.4)$ & $\begin{array}{l}15.0 \\
(7.6)\end{array}$ & $\begin{array}{l}11.0 \\
(3.1)\end{array}$ \\
\hline & Total & $-\mathrm{N}$ & $\begin{array}{c}19.8 \\
(12.0)\end{array}$ & $\begin{array}{c}25.4 \\
(10.1)\end{array}$ & $\begin{array}{l}17.2 \\
(4.2)\end{array}$ \\
\hline \multirow{3}{*}{$\begin{array}{l}\text { Oven-drying } \\
\text { and } \\
\text { rewetting }\end{array}$} & Rice & straw-N & $\begin{array}{c}18.1 \\
(32.2)\end{array}$ & $\begin{array}{c}12.2 \\
(23.0)\end{array}$ & $\begin{array}{c}7.0 \\
(12.6)\end{array}$ \\
\hline & Soil & $-\mathrm{N}$ & $\begin{array}{c}17.5 \\
(16.1)\end{array}$ & $\begin{array}{c}26.7 \\
(13.5)\end{array}$ & $\begin{array}{l}18.6 \\
(5.3)\end{array}$ \\
\hline & Total & $-\mathrm{N}$ & $\begin{array}{c}35.6 \\
(21.6)\end{array}$ & $\begin{array}{c}38.9 \\
(15.5)\end{array}$ & $\begin{array}{l}25.6 \\
(6.3)\end{array}$ \\
\hline
\end{tabular}

Figures in parentheses showed the percentage of mineralization of organic $\mathrm{N}$ of residual soil derived from rice straw- $\mathrm{N}$ and the native soil- $\mathrm{N}$, respectively. 

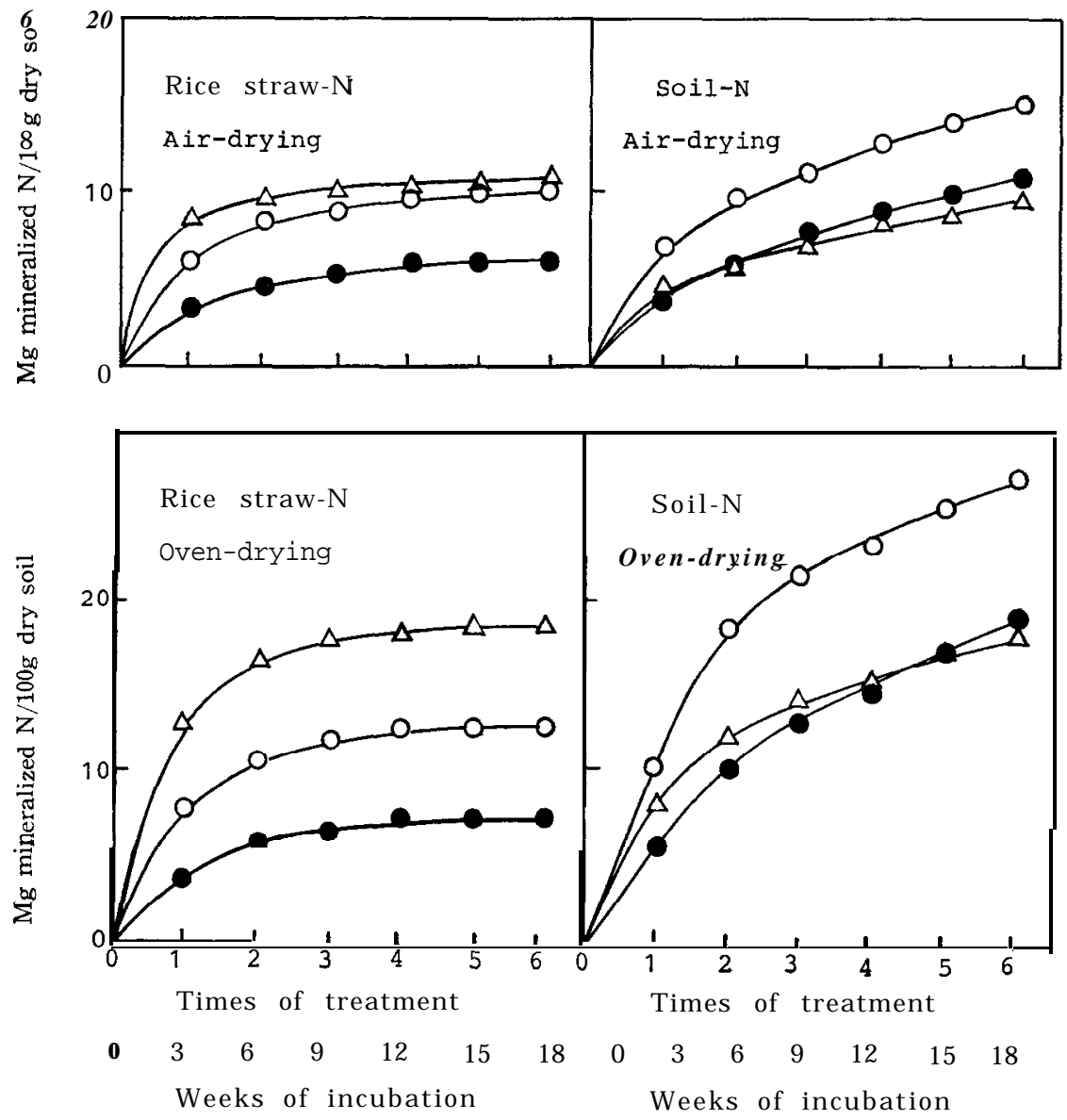

Fig. 1 Cumulative mineralized nitrogen derived from rice straw-N and soil-N during 6 times repeated either air-drying or oven-drying, rewetting and incubation of residual soils.

O: Kasuya soil, $\Delta$ : Nagano soil, $\bigcirc$ : Miyakonojo soil.

and second treatments (the first 6 weeks of incubation), but it was rapidly tapered off thereafter. This might suggest a rapid reduction in the residual effect of rice straw application on the nitrogen supplying capacities of soil about 34 weeks after the application of rice straw.

The mineralized amount of native soil-N was also greater during the first two treatments but, as compared with that of rice straw-N, the mineralization continued at a fairly steady rate during the remaining 4 treatments and by the end of the experiment the amount of native soil- $\mathrm{N}$ mineralized equalled or exceeded the amount of rice straw-N mineralized. These results would account for the necessity of successively long-term application of rice straw to improve the soil fertility.

On the stronger desiccation of soils by oven-drying, the amounts of the 
mineralized nitrogen derived from both straw-N and native soil- $\mathrm{N}$ were more greatly increased. The release pattern of mineralized nitrogen by the ovendrying treatment was very similar to that by the air-drying one.

As shown in Table 1, the eventual mineralization amounts of rice straw- $\mathrm{N}$ in the course of 6 times repeated air-drying, rewetting and incubation of residual soils of Nagano, Kasuya and Miyakonojo were 10.7, 10.4 and $6.2 \mathrm{mg} \mathrm{N}$ per $100 \mathrm{~g}$ dry soil, and those of soil-N were $9.1,15.0$ and $11.0 \mathrm{mg} \mathrm{N}$ per $100 \mathrm{~g}$ dry soil, respectively. The residual nitrogen derived from rice straw was more susceptible to mineralization than that of the soil-N due to both air-drying and oven-drying of soils. In addition, the stronger desiccation process of ovendrying of soils promoted the mineralization of soil-N about twofold as much as that produced when the residual soils were air-dried and rewetted. These indicated that the residual organic nitrogen in soils derived from the amended rice straw composed a easily decomposable fraction to mineralization, and the mineralization of the native soil-N was substantially enhanced on the stronger desiccation of oven-drying of soils.

Besides, the mineralization of nitrogen derived from rice straw was greatly intensified by the oven-drying treatment in Nagano soil in particular out of three soils, which contained montmorillonite as a predominant clay mineral. This finding agrees with that the accumulation of easily decomposable organic matter more progressed in the soils rich in $2: 1$ layer clay minerals through the formation of clay-organic nitrogen complex (Ensminger et al., 1959 ; Marumoto and Kai, 1978).

In Miyakonojo soil, the mineralization of both rice straw-N and soil- $\mathrm{N}$ were lower, since the reserves of decomposable nitrogen in residual soil may have been depleted by the high priming effect during the mineralization process of added rice straw (Masayna et al., 1985, Kawaguchi et al., 1986).

\section{Transformation of fixed ammonium derived from rice straw- $\mathrm{N}$ and soil- $\mathrm{N}$ in the mineralization process of rice straw}

The effect of rice straw application on the transformation of fixed ammonium in soils during 28 weeks' incubation, following the 6 times repeated drying, rewetting and incubation of the residual soils was investigated.

Table 2 showed the amounts of fixed ammonium of the soils before and after the incubation of rice straw, following the repeated either air-drying or oven-drying, rewetting and incubation of the residual soils. Moreover, Table 3 gave the amounts and percentages of gains of fixed ammonium derived from rice straw-N and soil-N on the incubation. The amounts of gains were calculated as the differences between the amounts of fixed ammonium after 28 weeks' incubation in the soil with rice straw and those in the soil without rice straw, and between the amounts of fixed ammonium of the repeated either air-drying or oven-drying of residual soils and those of 28 weeks' incubation of soils amended with rice straw, respectively. Percentage gains (figures in parentheses) were expressed as the percentage of the cumulative mineralized nitrogen in each fraction of both rice straw-N and soil-N on the incubation.

It has been known that the fixed ammonium substantially occurs in the soils 
Table 2. Amounts of fixed ammonium derived from rice straw- $\mathrm{N}$ and soil-N before and after 28 weeeks' incubation of soils amended with or without rice straw, and after following the successively repeated drying, rewetting and incubation of residual soils, expressed as $\mathrm{mg} \mathrm{N}$ per $100 \mathrm{~g}$ dry soil.

\begin{tabular}{|c|c|c|c|c|c|c|c|c|c|}
\hline \multirow[b]{2}{*}{ Soil } & \multicolumn{3}{|c|}{ Nagano } & \multicolumn{3}{|c|}{ Kasuya } & \multicolumn{3}{|c|}{ Miyakonojo } \\
\hline & $\begin{array}{l}\text { Rice } \\
\text { straw } \\
\mathrm{N}\end{array}$ & $\begin{array}{c}\text { Soil } \\
\mathrm{N}\end{array}$ & $\begin{array}{c}\text { Total } \\
\mathrm{N}\end{array}$ & $\begin{array}{c}\text { Rice } \\
\text { straw } \\
N\end{array}$ & $\begin{array}{c}\text { Soil } \\
\mathrm{N}\end{array}$ & $\begin{array}{c}\text { Total } \\
\mathrm{N}\end{array}$ & $\begin{array}{c}\text { Rice } \\
\text { straw } \\
\text { N }\end{array}$ & $\begin{array}{c}\text { Soil } \\
\mathrm{N}\end{array}$ & $\begin{array}{c}\text { Total } \\
\mathrm{N}\end{array}$ \\
\hline & \multicolumn{9}{|c|}{ Original soils } \\
\hline & 一 & 30.98 & & -- & 7.02 & & $-\ldots$ & 4.14 & - \\
\hline & \multicolumn{9}{|c|}{28 weeks' incubation of soils amended with or without rice straw } \\
\hline & & 30.06 & - & - & 6.81 & & & 4. 16 & \\
\hline \multirow{2}{*}{ With rice straw } & 0.06 & 29.80 & 29.86 & 0.21 & 6.09 & 6.30 & 0.01 & 3.19 & 3.20 \\
\hline & \multicolumn{9}{|c|}{ Repeated air-drying, rewetting and incubation of residual soils* } \\
\hline 2 times & 0.15 & 30.50 & 30.65 & 0.24 & $\begin{array}{l}6.33 \\
672\end{array}$ & 6.57 & 0.07 & 3.09 & 3.16 \\
\hline & \multicolumn{9}{|c|}{ Repeated oven-drying, rewetting $82 \frac{1}{1}$ inca'noion of residual soils* } \\
\hline 2 times & 0.97 & 30.94 & 31.91 & 1.03 & 8.67 & 9.99 & 0.10 & 3.18 & 3.28 \\
\hline 6 times & 1.08 & 31.28 & 32.36 & 1.32 & & & 0.17 & 3.49 & 3.66 \\
\hline
\end{tabular}

* Residual soils : soils after 28 weeks' incubation amended with rice straw.

containing 2 : 1 clay mineral such as montmorillonite, vermiculite and illite (Broadbent, 1979). In the original soils used in this experiment, the amounts of native soil fixed ammonium per $100 \mathrm{~g}$ dry soil and their proportions of total nitrogen were highest in Nagano soil rich in montmorillomite: $30.98 \mathrm{mg} \mathrm{N}$ and $22.3 \%$, followed by Kasuya soil contained meta-halloysite and vermiculite : 7.02 $\mathrm{mg} \mathrm{N}$ and $2.9 \%$, and lowest in Miyakonojo soil of allophane and imogolite : $4.14 \mathrm{mg} \mathrm{N}$ and $1.1 \%$, respectively.

A small portion of rice straw-N mineralized during 28 weeks' decomposition of rice straw was fixed by soils. The percentages of newly fixed rice straw-N only ranged from 0.05 to $1.44 \%$ of the amounts of mineralized nitrogen from rice straw. On the other hand, the amounts of the native soil fixed ammonium of Nagano and Kasuya soils without rice straw, referred to check soil, were slightly decreased in the course of incubation, but that of Miyakonojo soil was a little bit increased. On the incubation of soils amended with rice straw, much more amounts of the native soil fixed ammonium were released than those of the check soils. Consequently, the sum total of remained soil fixed ammonium and newly fixed ammonium derived from rice straw-N of the amended soils became lower than that of check soils. The differences in the amounts of the native soil fixed ammonium between the check soils without rice straw and soils with rice straw were the promoted release of fixed ammonium, the so-called priming effect, due to the application of rice straw. The magnitudes of priming effect per $100 \mathrm{~g}$ dry soil and their proportions of the native fixed ammonium of original soils were in the following way; largest in Miyakonojo soil: $0.97 \mathrm{mg} \mathrm{N}$ and $23.4 \%$, followed by Kasuya soil : $0.72 \mathrm{mg} \mathrm{N}$ and $10.3 \%$, and smallest in Nagano soil: $0.26 \mathrm{mg} \mathrm{N}$ and $0.8 \%$. Those of the 
Table 3. Gains of fixed ammonium derived from rice straw- $\mathrm{N}$ and soil-N after 28 weeks' incubation of soils amended with rice straw, and after following the successively repeated drying, rewetting and incubation of residual soils, expressed as mg N per $100 \mathrm{~g}$ dry soil.

\begin{tabular}{|c|c|c|c|c|c|c|c|c|c|}
\hline \multirow[b]{2}{*}{ Soil } & \multicolumn{3}{|c|}{ Nagano } & \multicolumn{3}{|c|}{ Kasuya } & \multicolumn{3}{|c|}{ Miyakonojo } \\
\hline & $\begin{array}{l}\text { Rice } \\
\text { straw } \\
\mathrm{N}\end{array}$ & $\begin{array}{c}\text { Soil } \\
\mathrm{N}\end{array}$ & $\begin{array}{c}\text { Total } \\
\mathrm{N}\end{array}$ & $\begin{array}{l}\text { Rice } \\
\text { straw } \\
\mathrm{N}\end{array}$ & $\begin{array}{c}\text { Soil } \\
\mathrm{N}\end{array}$ & $\begin{array}{c}\text { Total } \\
\mathrm{N}\end{array}$ & $\begin{array}{l}\text { Rice } \\
\text { straw } \\
\text { N }\end{array}$ & $\begin{array}{c}\text { Soil } \\
\mathrm{N}\end{array}$ & $\begin{array}{c}\text { Total } \\
\mathrm{N}\end{array}$ \\
\hline \multicolumn{10}{|c|}{28 weeks' incubation of soils amended with rice straw } \\
\hline & $\begin{array}{l}0.06 \\
(0.47)\end{array}$ & $\begin{array}{c}\mathbf{1 . 1 8} \\
(-21.45)\end{array}$ & $\begin{array}{l}-1.12 \\
(-6.09)\end{array}$ & $\begin{array}{c}0.21 \\
(1.44)\end{array}$ & $\begin{array}{l}-0.93 \\
(-8 . \quad 45)\end{array}$ & $\begin{array}{l}-0.72 \\
(-2.81)\end{array}$ & $\begin{array}{l}0.01 \\
(0.05)\end{array}$ & $\begin{array}{l}-0.95 \\
(-6.83)\end{array}$ & $\begin{array}{l}-0.94 \\
(-2.92)\end{array}$ \\
\hline \multicolumn{10}{|c|}{ Repeated air-drying, rewetting and incubation of residual soils } \\
\hline $\begin{array}{l}2 \text { times } \\
6 \text { times }\end{array}$ & $\begin{array}{c}0.09 \\
(1.06) \\
0.07 \\
(0.65)\end{array}$ & $\begin{array}{c}0.70 \\
(10.45) \\
0.93 \\
(10.22)\end{array}$ & $\begin{array}{c}\mathbf{0 . 7 9} \\
(5.19) \\
1.00 \\
(5.05)\end{array}$ & $\begin{array}{l}\mathbf{0 . 0 3} \\
(0.37) \\
0.08 \\
(0.77)\end{array}$ & $\begin{array}{c}0.24 \\
(2.37) \\
0.19 \\
(1: 27)\end{array}$ & 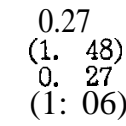 & $\begin{array}{l}0.06 \\
(1.33) \\
0.05 \\
(0: 81)\end{array}$ & $\begin{array}{c}-0.10 \\
(-1.72) \\
-0.08 \\
(-0: 73)\end{array}$ & $\begin{array}{l}-0.04 \\
(-0.39) \\
-0.03 \\
(-0: 17)\end{array}$ \\
\hline \multicolumn{10}{|c|}{ Repeated oven-drying, rewetting and incubation of residual soils } \\
\hline 2 times & $\begin{array}{c}0.91 \\
(5.65)\end{array}$ & $\begin{array}{c}1.14 \\
(9.57)\end{array}$ & $\begin{array}{c}2.05 \\
(7.32)\end{array}$ & $\begin{array}{l}0.82 \\
(7.96)\end{array}$ & $\begin{array}{c}2.16 \\
(11.87)\end{array}$ & $\begin{array}{r}2.98 \\
(10.46)\end{array}$ & $\begin{array}{c}0.09 \\
(1.58)\end{array}$ & $\left(\begin{array}{l}-0.01 \\
-0.10)\end{array}\right.$ & $\begin{array}{r}0.08 \\
0.51\end{array}$ \\
\hline 6 times & $\begin{array}{l}1.02 \\
(5.64)\end{array}$ & $\begin{array}{l}\text { (1. } 48 \\
\text { (8: } 46)\end{array}$ & $\begin{array}{r}2.50 \\
(7.02)\end{array}$ & a. 11 & $\begin{array}{r}2.58 \\
(9.66)\end{array}$ & $\begin{array}{l}2.69 \\
(9.49\end{array}$ & $\begin{array}{l}\text { (2. } 16 \\
(2.29)\end{array}$ & $\begin{array}{l}0.30 \\
(1: 61)\end{array}$ & $\begin{array}{l}0.46 \\
(1: 80)\end{array}$ \\
\hline
\end{tabular}

Figures in parentheses were calculated as percentage of mineralized nitrogen of straw-N and soil-N during the incubation, respectively.

priming effect due to the application of rice straw were approximately in inverse proportion to the amounts of the native soil fixed ammonium of original soils. The rice straw application to the soils caused the priming effects concerning not only the enhanced decomposition of soil native organic matter (Masayna et al., 1985 ; Kawaguchi et al., 1986), but also the promoted release of the native fixed ammonium. The increase in the release of fixed ammonium would be presumed to be due to the stimulation of the activities of nitrifying bacteria as well as those of heterotrophic microorganisms by the addition of rice straw to the soils which enhanced the microbial utilization of fixed ammonium (Black and Waring, 1972).

The amounts of fixed ammonium derived from rice straw-N slightly increased in periodically air-dried, rewetted and incubated residual soils, which ranged from 0.03 to $0.09 \mathrm{mg} \mathrm{N}$ per $100 \mathrm{~g}$ dry soil. The fixed ammonium derived from soil-N also a little increased in Nagano and Kasuya soils, while that in Miyakonojo soil decreased a little bit through the 6 times air-drying treatments.

It was noteworthy that the repeated oven-drying, rewetting and incubation of the residual soils led to a marked increase of the fixed ammonium derived from rice straw-N and soil-N. Those processes of ammonium fixation gradually continued by the end of the experiment. The eventual percentages of newly fixed rice straw-N of the amounts of mineralized nitrogen from the rice straw$\mathrm{N}$ were largest in Kasuya soil : $9.1 \%$, followed by Nagano soil: $5.6 \%$, and smallest in Miyakonojo soil : 2.3\%. Those of soil-N were 9.7\% in Kasuya soil, $8.5 \%$ in Nagano soil and $1.6 \%$ in Miyakonojo soil, decreasing that order.

The content and transformation of fixed ammonium in soil are greatly af- 
fected by many factors such as the composition of clay minerals, soluble and exchangeable ammonium, soil moisture, coexistent potassium, oxidation-reduction potential and so on (Kai and Wada, 1979). These relationships should be confirmed by the further studies.

\section{Chemical nature of the decomposable organic nitrogen due to the drying of the residual soils}

The effect of repeated either air-drying or oven-drying, rewetting and incu-

Table 4. The distribution of different forms of organic nitrogen derived from rice straw- $\mathrm{N}$ and soil- $\mathrm{N}$ in residual soils before and after 6 times repeating of drying, rewetting and incubation, expressed as $\mathrm{mg} \mathrm{N}$ per $100 \mathrm{~g}$ dry soil.

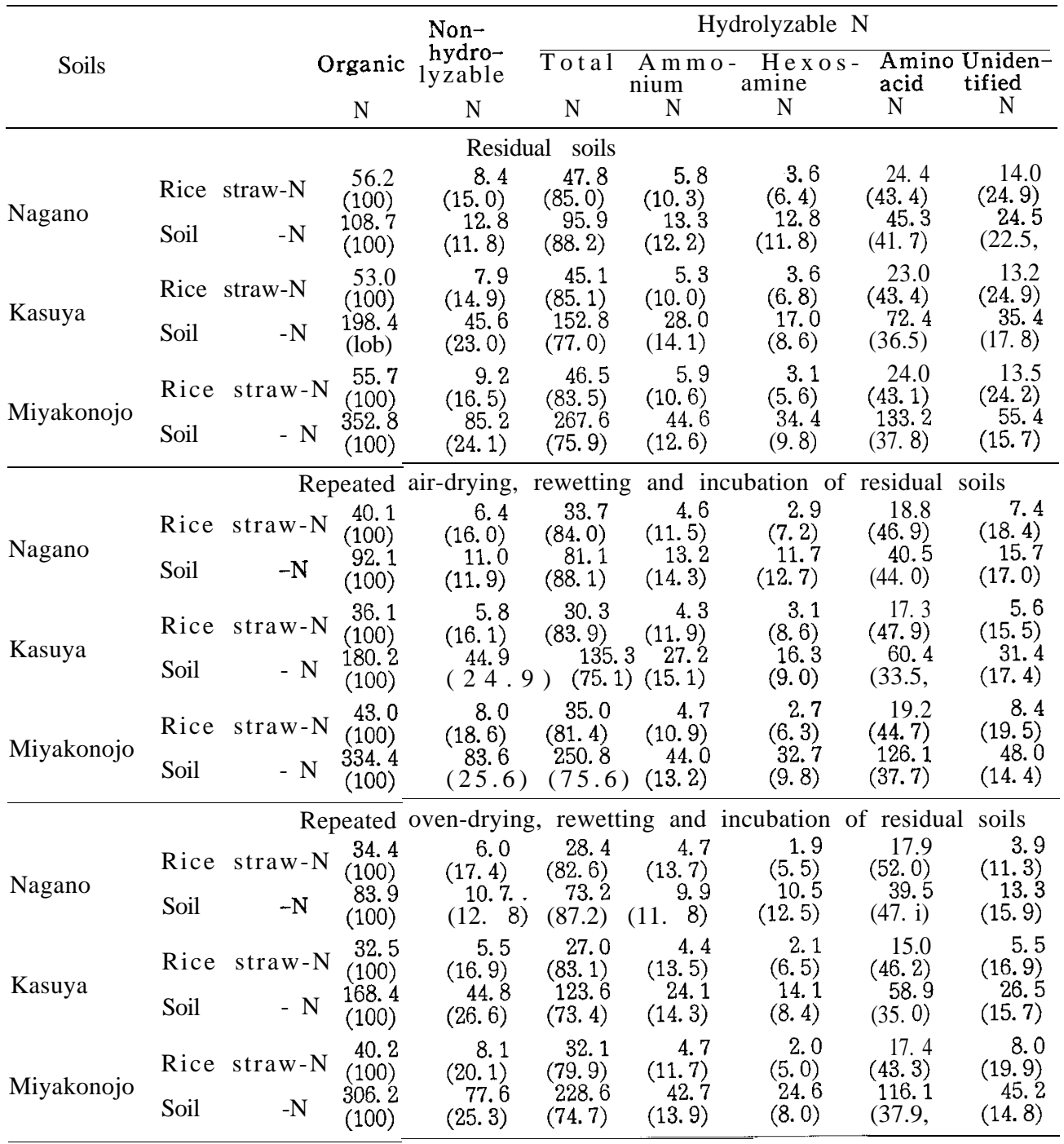

Figures in parentheses showed percentage of organic $\mathrm{N}$ of rice straw-N and soil-N, respectively. 
bation of residual soils on the nitrogen distribution in acid hydrolysates derived from rice straw- $\mathrm{N}$ and the native soil-N of three residual soils amended with ${ }^{15} \mathrm{~N}$-labelled rice straw was investigated.

Table 4 showed the distribution of different forms of organic nitrogen derived from rice straw-N and soil-N before and after the drying treatments, respectively. The largest proportion of the rice straw-N in three residual soils was present in amino acid-N, followed by unidentified-N, non-hydrolyzable- $\mathrm{N}$, ammonium-N and hexosamine-N, decreasing that order. As compared with the native soil-N, rice straw-N of the residual soils was found more in amino acid-N and unidentified-N, and comparable percentages were present in hexosamine- $\mathrm{N}$ and ammonium-N of the acid hydrolyzable-N. The various forms of organic nitrogen derived from rice straw-N approached what was natively constituted in the soils for a comparatively short periods of 28 weeks' incubation. It was noteworthy that the residual soils contained a appreciable amounts of hexosamine-N, ranging from 5.6 to $6.8 \%$ of organic nitrogen, derived from rice straw-N in which hexosamine-N was scarcely detected at all. It is well known that hexosamine is the principal constituent of microbial cell wall, since it was newly synthesized through the microbial decomposition of rice straw and became accumulated in the residual soils due to the resistance to the decomposition in soils (Marumoto et al., 1972 ; Kai et al., 1973).

The previously drying treatments led to a decrease in the organic nitrogen of both rice straw-N and soil-N, and the decrease was much more marked in the repeated oven-dried and rewetted soils than in the repeated air-dried and rewetted soils. The repeated air-drying, rewetting and incubation of the residual soils caused a decrease in the amounts of various forms of organic nitrogen, and the decrease was found large in unidentified-N and amino acid-N, and small in hexosamine- $\mathrm{N}$ and ammonium- $\mathrm{N}$. The data on the percentage distribution (figures in parentheses) of different forms of hydrolyzable-N showed that a general tendency to detect as a result of the repeated drying processes was a appreciable decrease in the percentage of unidentified-N, and small increases of amino acid-N, ammonium-N and hexosmine-N.

Table 5 gave the amounts and percentages of losses of different forms of nitrogen on the incubation. The amounts of losses were calculated as the difference between the amount of nitrogen in the each fraction for the residual soils and that after the successive incubation. The percentage contribution of different forms of nitrogen (figures in parentheses) to the nitrogen mineralization was calculated as a percentage of the organic nitrogen loss in each soil sample. It indicated the distribution of the nitrogen lost during the incubation. Table 5 showed that mineralized amounts of rice straw-N and native soil-N after 6 times repeated air-drying, rewetting and incubation of the residual soils ranged from 12.7 to $16.9 \mathrm{mg} \mathrm{N}$ for the rice straw- $\mathrm{N}$, and from 16.6 to $18.4 \mathrm{mg} \mathrm{N}$ per $100 \mathrm{~g}$ dry soil for the soil-N, respectively. Besides, those of oven-drying, rewetting and incubation of residual soils ranged from 15.5 to $21.8 \mathrm{mg} \mathrm{N}$ for rice straw-N, and from 24.8 to $46.6 \mathrm{mg} \mathrm{N}$ per $100 \mathrm{~g}$ dry soil for soil-N, respectively. These indicated that the mineralization of both rice straw$\mathrm{N}$ and soil-N was more accelerated through the effect of oven-drying than that 
Table 5. Losses of different forms of rice straw-N and soil-N on the repeated either air-drying or oven-drying, rewetting and incubation of residual soils, calculated as $\mathrm{mg} \mathrm{N}$ of loss per $100 \mathrm{~g}$ dry soil.

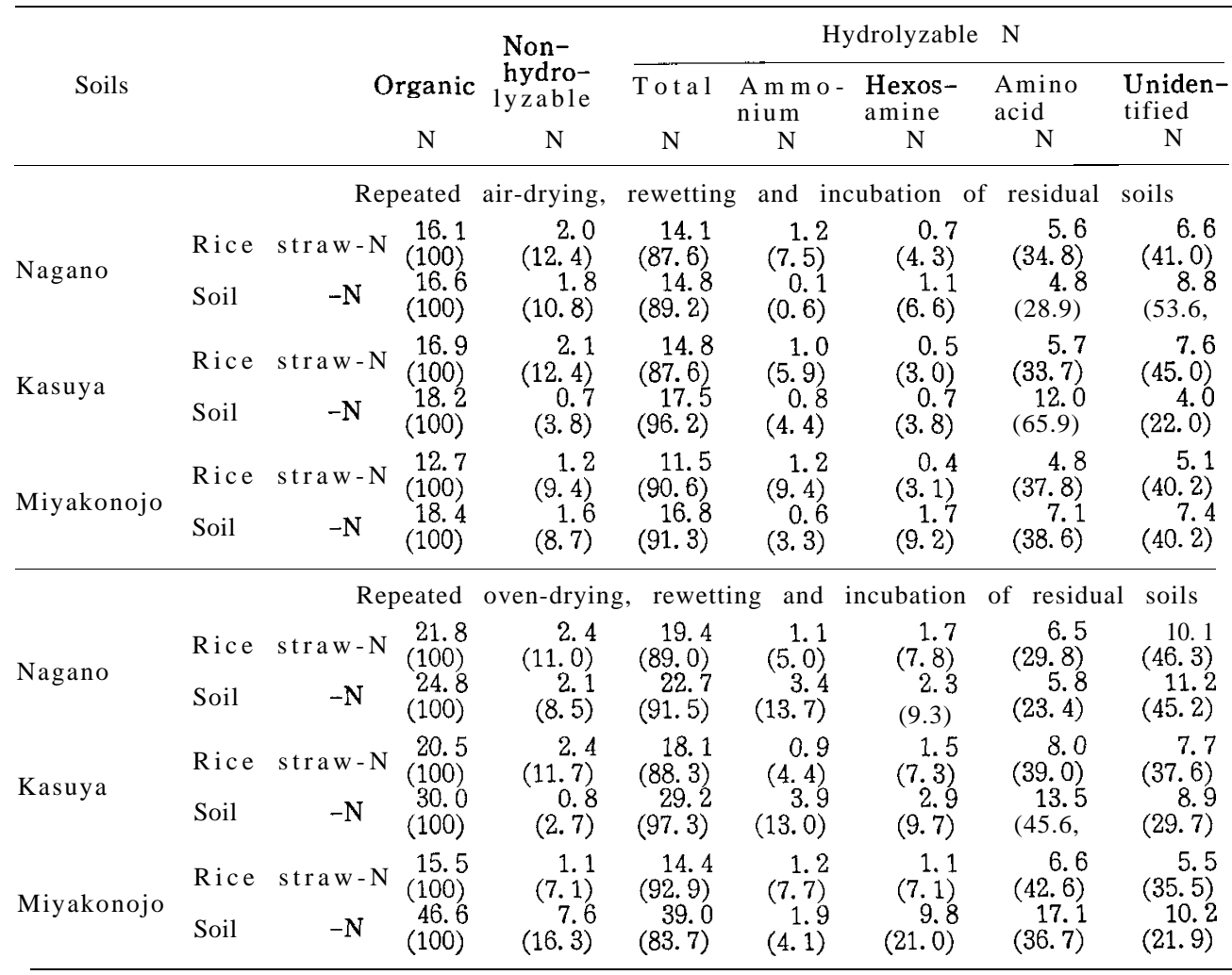

Figures in parentheses were calculated as percentage of organic $\mathrm{N}$ loss of straw-N and soil-N, respectively.

of air-drying.

The previous air-drying and oven-drying treatments of the soil samples led to a larger decrease in the amount of hydrolyzable-N than in that of nonhydrolyzable-N. Among the various forms of hydrolyzable-N, major fractions of both rice straw-N and soil-N contributing to mineralization process on the incubation of air-dried samples were unidentified-N ; 40.2 to $45.0 \%$ for rice straw-N, 22.0 to $53.0 \%$ for soil-N, and amino acid-N; 33.7 to $37.8 \%$ for rice straw-N, 28.9 to $65.9 \%$ for soil-N, followed by ammonium-N, 5.9 to $9.4 \%$ for rice straw-N, 0.6 to $4.4 \%$ for soil-N, and hexosamine-N; 3.0 to $4.3 \%$ for rice straw-N, 3.8 to $9.2 \%$ for soil-N. On the incubation of oven-dried soils, the amounts of losses of unidentified-N and amino acid-N of both rice straw-N and soil-N were increased, but their variations of the percentage distribution due to the effect of oven-drying was obscure. Besides, the amounts of losses and percentage distribution of hexosamine- $\mathrm{N}$ in both rice straw- $\mathrm{N}$ and soil- $\mathrm{N}$ were significantly heightened through oven-drying of soils. In the case of 
Table 6. The rate of mineralization of each $\mathrm{N}$ fraction of the rice straw- $\mathrm{N}$ and soil- $\mathrm{N}$, calculated as percentage of the $\mathrm{N}$ in that form of each residual soils.

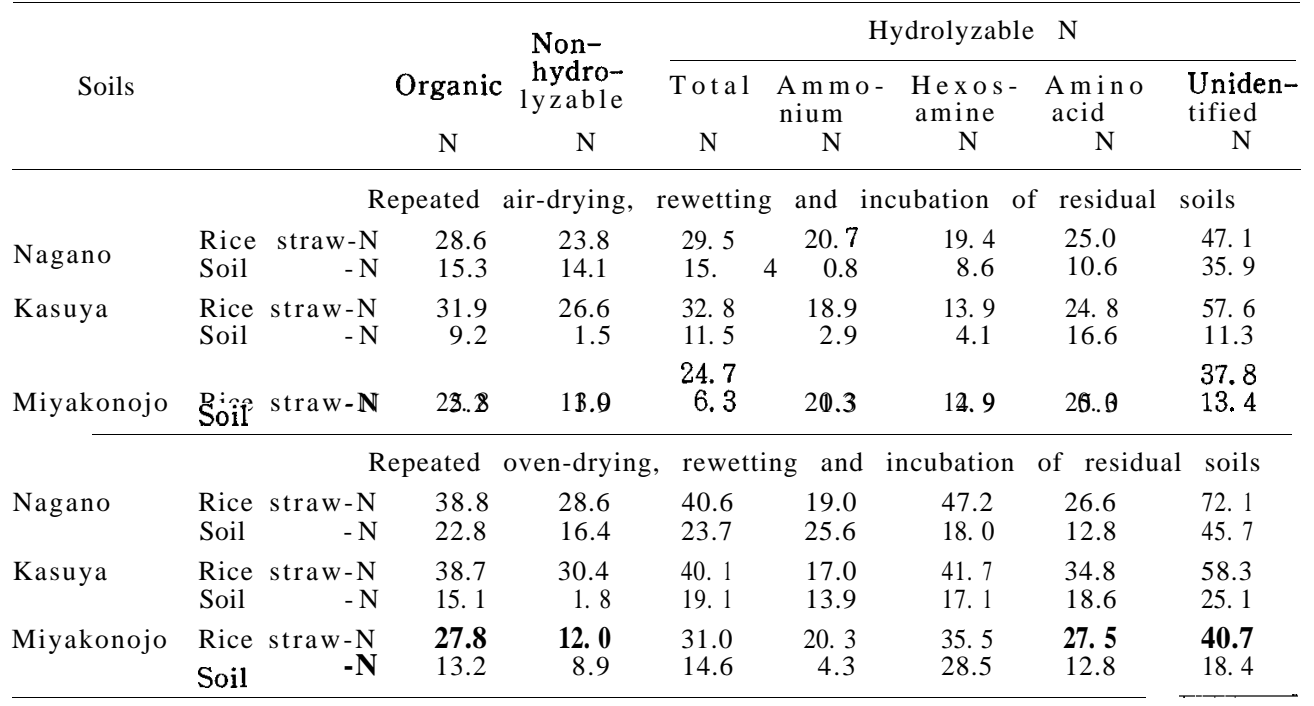

hydrolyzable ammonium-N for soil-N, its amounts of losses and the percentage distribution were also intensified, but those of rice straw-N decreased to a slight degree on the incubation of oven-dried soils.

Table 6 gave the rate of mineralization of each nitrogen fraction of rice straw- $\mathrm{N}$ and soil- $\mathrm{N}$ on the incubation, calculated as a percentage of the nitrogen in that form of the residual soils. The figures in this table indicated the susceptibility of each forms of nitrogen to the mineralization due to the repeated either air-drying or oven-drying of soils. The each rate of various forms of organic nitrogen derived from rice straw- $\mathrm{N}$ was larger than that from soil-N in both air-dried and oven-dried soils. Therefore, each fraction of organic nitrogen derived from rice straw-N was more susceptible to the mineralization than that of the native soil-N.

Among the various forms of organic nitrogen, unidentified-N was most susceptible to the mineralization, since the rates of mineralization of unidentified$\mathrm{N}$ of both rice straw-N and soil-N greatly exceeded those of organic nitrogen on the incubation of air-dried and oven-dried soils. The susceptibilities of hexosamine- $\mathrm{N}$ and ammonium-N were considerably lower than those of unidentified-N and amino acid-N due to the air-drying effect, but oven-drying of soils followed by rewetting and incubation significantly promoted the mineralization rate of hexosamine- $\mathrm{N}$ of both rice straw-N and soil- $\mathrm{N}$, and ammonium$\mathrm{N}$ of soil- $\mathrm{N}$ in addition of the fractions of unidentified-N and amino acid-N.

Furthermore, the mineralization rate of hexosamine- $\mathrm{N}$ derived from rice straw significantly exceeded that of organic nitrogen on the incubation of oven-dried soils. This suggested that microbial cell wall substances of which hexosamine$\mathrm{N}$ is the predominant component, contributed considerably to the decomposable soil organic nitrogen due to the oven-drying of residual soils. The above 
mentioned susceptibilities of various nitrogen fractions to the mineralization process through the drying of soils were almost the similar tendency as those found in the previous study which dealed with chemical nature of decomposable organic nitrogen newly immobilized in the soil receiving glucose and potassium nitrate labelled with ${ }^{15} \mathrm{~N}$ (Kai et al., 1973 ; Ahmad et al., 1973).

From the results obtained above, it was concluded that 1) the mineralization of rice straw-N was distinctly more accelerated through the effect of both airdrying and oven-drying of residual soils than that of the native soil-N, 2) as compared with native soil- $\mathrm{N}$, rice straw-N of residual soils was found more in unidentified-N and amino acid-N, and comparable percentages were present in ammonium- $\mathrm{N}$ and hexosamine- $\mathrm{N}$ in the acid hydrolyzable- $\mathrm{N}$ of organic nitrogen. Major sources of the nitrogen mineralized on the incubation existed in the fractions of unidentified-N and amino acid-N. The susceptibility of hexosamine$\mathrm{N}$ to mineralization of the air-dried soils was lower than that of other forms, but it was significantly intensified after oven-drying of soils, and 3) principal organic nitrogen compounds becoming decomposable due to a drying treatment would belong to mucopeptides and structural proteins originated from microbial cell walls which were remained as a residual nitrogen in soils.

\section{REFERENCES}

Ahmad, Z., Y. Yahiro, H. Kai and T. Harada 1973 Factors affecting immobilization and release of nitrogen in soil and chemical characteristics of the nitrogen newly immobilized. IV. Chemical nature of the organic nitrogen becoming decomposable due to the drying of soil. Soil Sci. Plant Nutr., 19: 287-298

Birch, H. F. 1958 The effect of soil drying on humus decomposition and nitrogen availability. Plant and Soil, 10: 9-36

Black, A. S. and S. A. Waring 1972 Ammonium fixation and availability in some cereal producing soils in Queensland. Aust.J.Soil Res., 10: 197-207

Bremner, J. M. 1965 Organic forms of nitrogen. In "Methods of Soil Analysis", Ed. by Black, D. A. et al., Agron. Ser. No. 9. American Society of Agronomy, Madison, Wisconsin, pp. 1238-1255

Broadbent, F. E. 1979 Mineralization of organic matter in paddy soils. In "Nitrogen and Rice”, Int. Rice Res. Inst., Los Bafios, pp. 105-118

Ensminger, L. E. and J. E. Gieseking 1942 Resistance of clay-adsorbed proteins to proteolytic hydrolysis. Soil Sci., 53: 205-210

Hayashi, R. and T. Harada 1969 Characterization of the organic nitrogen becoming decomposable through the effect of drying of a soil. Soil Sci. Plant Nutr., 15: 226-234

Kai, H. and T. Harada 1972 Determination of nitrate by a modified Conway microdiffusion analysis using Devarda's alloy as a reducing agent. Sci. Bull. Fac., Agr., Kyushu Univ., 26: 61-66 (in Japanese)

Kai, H., Z. Ahmad and T. Harada. 1973. Factors affecting immobilization and release of nitrogen in soil and chemical characteristics of the nitrogen newly immobilized. III. Transformation of the nitrogen immobilized in soil and its chemical characteristics. Soil Sci. Plant Nutr., 19: 275-286

Kai, H. and K. Wada 1979 Chemical and biological immobilization of nitrogen in paddy soils. In "Nitrogen and Rice", Int. Rice Res. Inst., Los Baños, pp. 157-174

Kawaguchi, S., H. Kai and T. Aibe 1986 Nitrogen dynamics in soils following the addition of ${ }^{15} \mathrm{~N}$-labelled rice straw. J. Fac. Agr., Kyushu Univ., 30: 247-252 
Masayna, W., H. Kai and S. Kawaguchi 1984 Tracer studies of the efficiency of rice straw nitrogen in Thai paddy soils. 5th ASEAN Soil Conference, H4.1-H4.6

Masayna, W., H. Kai and S. Kawaguchi 1985 Nitrogen behavior in tropical wetland rice soils. 2. The efficiency of fertilizer nitrogen, priming effect and A-values. Fert. Res., 6: $37-47$

Marumoto, T., K. Furukawa, T. Yoshida, H. Kai and T. Harada 1972 Effect of the application of rye-grass on the contents of individual amino acids and amino sugars contained in the organic nitrogen in soil. J.Fac. Agr., Kyushu Univ., 17: 37-47

Marumoto, T. and H. Kai 1978 Effect of drying on the mineralization of protein-colloidal complex in soil. J. Sci. Soil Manure, Japan, 49: 372-377 (in Japanese)

Silva, J. A. and J. M. Bremner 1966 Determination and isotope-ratio analysis of different forms of nitrogen in soil. 5. Fixed ammonium. Soil Sci. Soc. Amer. Proc., 30: 587-594 